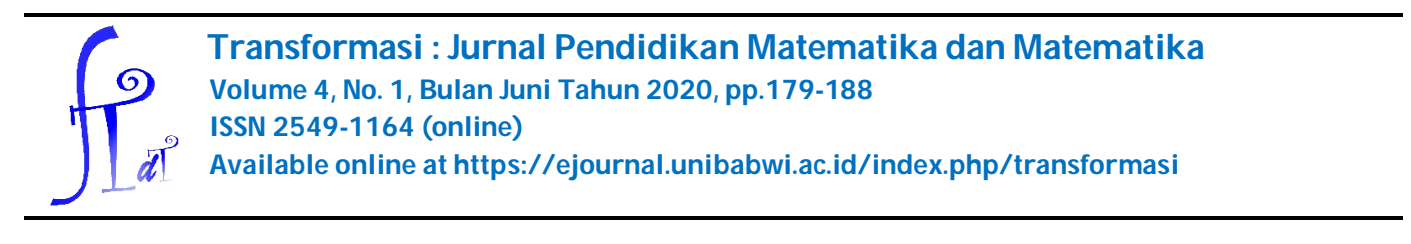

\title{
ANALISIS TINGKAT KECEMASAN SISWA DALAM MENGHADAPI UJIAN MATEMATIKA
}

\author{
Nabilah Fauziah ${ }^{1}$, Heni Pujiastuti ${ }^{2}$ \\ 1,2 FKIP, Universitas Sultan Ageng Tirtayasa \\ email korespondensi : nabilah.fauziah19@gmail.com
}

Diterima : 27-04-2020, Revisi: 31-05-2020, Diterbitkan : 25-06-2020

\begin{abstract}
ABSTRAK
PISA menyatakan bahwa Indonesia masih tergolong rendah dalam penguasaan materi. Karena sifat matematika yang dianggap sulit oleh sebagian besar siswa dan menimbulkan rasa cemas pada saat berhadapan dengan matematika, baik dalam pembelajaran atau dalam menghadapi evaluasi pembelajaran. Penelitian ini bertujuan untuk menganalisis tingkat kecemasan siswa dalam menghadapi ujian matematika. Jenis penelitian ini adalah penelitian kualitatif dengan pendekatan deskriptif. Subyek penelitian adalah siswa kelas XI SMA Negeri 23 Kabupaten Tangerang dan melibatkan 8 siswa secara acak tanpa mengetahui kemampuan awal siswa. Instrument yang digunakan untuk memperoleh adalah angket untuk mengetahui tingkat kecemasan siswa dalam menghadapi ujian matematika. Hasil penelitian ini menunjukkan bahwa tingkat kecemasan siswa terhadap ujian matematika sangat rendah. Kecemasan dalam tingkat yang rendah dan sedang berpengaruh positif terhadap penampilan belajar siswa, salah satunya dapat meningkatkan motivasi belajar. Karena kecemasan yang dialami siswa dapat dijadikan stimulus yang berguna bagi siswa itu sendiri. Menanamkan rasa percaya diri kepada siswa bahwa mereka bisa memahami dan menyelesaikan persoalan matematika serta menghilangkan prasangka negatif mengenai pelajaran matematika.
\end{abstract}

Kata kunci : kecemasan, matematika, ujian matematika 


\begin{abstract}
PISA declares that Indonesia is still relatively low in mastering material. Due to the nature of mathematics which is considered difficult by most students and causes anxiety when dealing with mathematics, both in learning or in the face of learning evaluation. This study aims to analyze the level of student anxiety in facing the mathematics test. This type of research is a qualitative research with a descriptive approach. The subjects of this study were class XI students of SMA Negeri 23 KabupatenTangerang and involved 8 students randomly without knowing the students' initial abilities. The instrument used to obtain data was a questionnaire in order to know the level of student anxiety in facing the mathematics test. The results of this study indicate that the level of student anxiety about mathematics test is very low. Anxiety in low and medium levels has a positive effect on student learning performance, one of which can increase learning motivation. Because anxiety experienced by students can be useful stimulus for students themselves. Instill confidence in students that they can understand and solve mathematical problems and eliminate negative prejudices about mathematics.
\end{abstract}

Keywords: anxiety, mathematics, mathematics test

\title{
Pendahuluan
}

Perkembangan ilmu pengetahuan dan teknologi telah membawa perubahan disemua aspek kehidupan manusia selaras dengan upaya meningkatkan kualitas sumber daya manusia. Pendidikan merupakan kegiatan mengoptimalkan perkembangan potensi, kecakapan dan karakteristik pribadi siswa. Pendidikan dapat mengembangkan potensi siswa baik itu fisik maupun psikis agar menjadi manusia yang berkualitas yang mampu bersaing di dunia pendidikan yang semakin maju ini (Agustina, Santoso, Jatisunda, \& Majalengka, 2019). Komponen-komponen yang terdapat dalam Pendidikan meliputi kurikulum, proses pembelajaran, dan evaluasi pembelajaran. Kegiatan evaluasi mempunyai peranan penting dalam pendidikan, begitu pula proses pembelajaran, karena dengan evaluasi dapat diketahui hasil dari kegiatan pembelajaran yang telah dilaksanakan dan untuk mengetahui perkembangan pendidikan, khususnya sistem pembelajaran bagi siswa selama mengikuti pendidikan, baik ditingkat dasar, menengah, maupun sekolah kejuruan. Salah satu evaluasi yang terdapat dalam dunia Pendidikan adalah ujian, baik ujian harian maupun ujian Nasional (Zahro \& Purwaningsih, 2018).

Peranan matematika dalam pendidikan tidak terlepas dari upaya pemerintah dalam memperbaiki kualitas pendidikan melalui evaluasi pembelajaran. Matematika merupakan disiplin ilmu yang sangat bermanfaat dalam kehidupan sehari- 
hari, dengan belajar metematika seseorang dilatih untuk berpikir kreatif, kritis, jujur dan dapat mengaplikasikan ilmu matematika dalam menyelesaikan suatu permasalahan dalam kehidupan sehari-hari maupun dalam disiplin ilmu lainnya. Pendidikan matematika mempunyai peran yang sangat penting karena matematika merupakan ilmu dasar yang digunakan secara luas dalam berbagai bidang kehidupan (Novferma, 2016). Belajar matematika dengan disertai pemahaman merupakan komponen terpenting dari kemampuan bersama dengan kecakapan pengetahuan faktual dan prosedural. Belajar matematika dengan disertai pemahaman sangat diperlukan untuk memungkinkan siswa menyelesaikan soal-soal atau permasalahan lain yang akan mereka hadapi dimasa yang akan datang (Handayani, 2016).

Di Indonesia, hasil tes dan evaluasi pada tahun 2015 yang dilakukan oleh Programme for International Students Assessment (PISA) melaporkan bahwa dari jumlah 540.000 siswa, Indonesia menduduki peringkat 63 dari 70 negara untuk matematika dengan skor 386. PISA menyatakan bahwa Indonesia masih tergolong rendah dalam penguasaan materi. Hal ini disebabkan oleh para siswa yang masih mengganggap matematika merupakan pelajaran yang sulit. Siswa yang menganggap matematika sebagai pelajaran yang relatif sulit kemudian membentuk kesan secara negatif terhadap matematika umumnya berdampak buruk baik bagi motivasi belajar matematika maupun penyesuaian akademik di sekolah (Siregar, 2017). Salah satu dampak buruknya adalah timbulnya kecemasan pada siswa. Bagi siswa kecemasan adalah suatu keadaan emosional yang tidak menenangkan seperti perasaan tertekan dalam menghadapi kesulitan saat mengerjakan soal latihan atau soal ujian matematika (Anfus, 2019). Kecemasan merupakan hal yang wajar yang pernah dialami oleh setiap individu dan tidak tertutup kemungkinan terjadinya kecemasan dalam belajar. Kecemasan matematika yang dialami oleh siswa bisa menyebabkan reaksi yang positif dan reaksi yang negatif (Nofrialdi, 2018).

Pada 2012, sekelompok peneliti yang dipimpin oleh Dr. Amy Devine dariUniversitas Cambridge tidak menemukan perbedaan jenis kelamin pada kinerja matematika antara siswa dan siswi. Pada dasarnya kecemasan dalam tingkat yang rendah dan sedang berpengaruh positif terhadap penampilan belajar siswa, salah satunya dapat meningkatkan motivasi belajar, sedangkan kecemasan siswa pada taraf yang tinggi dapat mengganggu dan memperburuk perilaku belajar siswa. Kecemasan siswa itu sendiri dilatarbelakangi oleh berbagai sebab. Kenyataan 
menunjukkan bahwa kecemasan siswa terhadap matematika tidak hanya dialami oleh siswa yang mempunyai kemampuan yang rendah dalam matematika. Berbagai faktor eksternal dari lingkungan sekitar siswa juga memberikan pengaruh terhadap kecemasan matematika siswa (Indiyani \& Listiara, 2006). Ada siswa yang dapat dengan mudah memahami ketika menerima suatu penjelasan, tetapi ada pula siswa yang tidak. Jika siswa yang tidak mengerti tersebut merasa cemas maka mereka tidak akan ragu untuk berusaha lebih keras untuk memahami. Tetapi, kecemasan yang berlebihan juga berdampak buruk pada diri mereka karena dapat mengurangi efektivitas dari usaha yang mereka lakukan. Ketika kecemasan meningkat pada diri siswa maka siswa tersebut akan berusaha lebih keras, tetapi pemahaman mereka justru semakin memburuk yang berakibat kecemasan mereka justru semakin meningkat (Wicaksono \& Saufi, 2013).

Dikarenakan sifat matematika yang dianggap sulit oleh sebagian besar siswa dan menimbulkan rasa cemas pada saat berhadapan dengan matematika, baik dalam pembelajaran ataupun dalam menghadapi evaluasi pembelajaran. Hal tersebut berakibat pada rata-rata nilai ujian matematika siswa pada tahun sebelumnya selalu rendah (Zahro \& Purwaningsih, 2018). Hasil belajar seringkali digunakan sebagai tolak ukur untuk mengetahui ukuran seberapa jauh seseorang menguasai bahan yang diajarkan (Wagetama. I, Dariyo, \& Basaria, 2014). Oleh sebab itu, setiap orang tua berusaha untuk mendorong anaknya agar berprestasi atau menjadi juara kelas. Tentu saja, hal ini akan berdampak pada anak itu sendiri (khususnya remaja) yang mengalami putus asa, karena tidak diperhitungkan prestasinya pada bidang atau keahlian yang lain selain pada bidang akademik (Anfus, 2019). Berbeda dengan siswa yang merasa kurang cemas karena siswa tersebut mengetahui bahwa ia mampu mengatasi masalah yang dihadapi maka ia akan dapat menggunakan kecemasaannya dalam menyelesaikan masalah. Berdasarkan hasil studi tersebut terlihat bahwa kecemasan yang dialami siswa dapat dijadikan stimulus yang berguna bagi siswa itu sendiri. Menanamkan rasa percaya diri kepada siswa bahwa mereka bisa memahami dan menyelesaikan persoalan matematika, serta menghilangkan prasangka negatif mengenai pelajaran matematika merupakan hal yang dapat dilakukan untuk meminimalkan kecemasan siswa pada pelajaran matematika (Wicaksono \& Saufi, 2013).

Berdasarkan uraian diatas, peneliti akan mendeskripsikan tingkat kecemasan yang dialami siswa terhadap ujian matematika. Dengan demikian, tujuan peneli- 
tian ini adalah untuk menganalisis tingkat kecemasan siswa dalam menghadapi ujian matematika.

\section{MetodePenelitian}

Jenis penelitian ini adalah penelitian deskriptif dengan pendekatan kualitatif. Penelitian ini dilaksanakan di kelas XI SMA Negeri 23 Kabupaten Tangerang. Pengukuran kecemasan siswa dilihat selama proses pembelajaran berlangsung, dan pada saat ujian dilaksanakan. Pengukuran ini bertujuan untuk melihat tingkat kecemasan siswa dalam menghadapi ujian matematika.

Subyek penelitian ini adalah siswa kelas XI SMA Negeri 23 Kabupaten Tangerang dan melibatkan 8 siswa secara acak tanpa mengetahui kemampuan awal siswa. Instrument yang digunakan untuk memperoleh data dalamp enelitian ini adalah angket untuk mengetahui tingkat kecemasan yang dirasakan siswa dalam menghadapi ujian matematika. Analisis data hasil angket dilakukan dengan menghitung skor yang diperoleh masing-masing siswa. Kemudian hasil data diklasifikasikan atau dikelompokan berdasarkan skor yang diperolehnya. Adapun rentang pengklasifikasian skor angket beserta analisis dari skor angket tersebut, dapat dilihat pada tabel 1.

Tabel 1. Keterangan Skor Mengenai Kecemasan Siswa Terhadap Ujian Matematika

\begin{tabular}{|c|c|}
\hline Skor & Keterangan \\
\hline $40-50$ & $\begin{array}{l}\text { Tidak memiliki masalah kecemasan terhadap ujian } \\
\text { matematika }\end{array}$ \\
\hline $30-39$ & $\begin{array}{l}\text { Belum bisa dipastikan apakah terindikasi masalah ke- } \\
\text { cemasan terhadap ujian matematika atau tidak }\end{array}$ \\
\hline $20-29$ & $\begin{array}{l}\text { Terindikasi kecemasan terhadap ujian matematika da- } \\
\text { lam kategori tingkat rendah (masih kesulitan dengan } \\
\text { matematika) }\end{array}$ \\
\hline $10-19$ & Terindikasi kecemasan terhadap ujian matematika \\
\hline
\end{tabular}

Data yang diperoleh kemudian dianalisis dengan memilah hasil angket sesuai dengan kebutuhan penelitian. Hasil analisis tersebut disajikan dalam bentuk uraian, sehingga memudahkan dalam menarik kesimpulan sesuai kebutuhan penelitian.

\section{Hasil dan Pembahasan}

Dalam penelitian ini peneliti mengumpulkan infomasi melalui tanggapan angket 
mengenai analisis tingkat kecemasan siswa dalam menghadapi ujian matematika. Angket terdiri dari 25 butir pernyataan. Angket tersebut secara umum meliputi bagaimana kecemasan siswa terhadap ujian matematika. Adapun hasil penelitian yang diperoleh sebagai berikut.

Tabel 2. Analisis Data Angket Tingkat Kecemasan terhadap Ujian Matematika

\begin{tabular}{|c|c|c|}
\hline Skor & Keterangan & Persentase (\%) \\
\hline $40-50$ & $\begin{array}{l}\text { Tidak memiliki masalah kecemasan terhadap } \\
\text { ujian matematika }\end{array}$ & $50 \%$ \\
\hline $30-39$ & $\begin{array}{l}\text { Belum bisa dipastikan apakah terindikasi } \\
\text { masalah kecemasan terhadap ujian matema- } \\
\text { tika atau tidak }\end{array}$ & $37,5 \%$ \\
\hline $20-29$ & $\begin{array}{l}\text { Terindikasi kecemasan terhadap ujian mate- } \\
\text { matika dalam kategori tingkat rendah (masih } \\
\text { kesulitan dengan matematika) }\end{array}$ & $12,5 \%$ \\
\hline $10-19$ & $\begin{array}{l}\text { Terindikasi kecemasan terhadap ujian mate- } \\
\text { matika }\end{array}$ & 0 \\
\hline
\end{tabular}

Berdasarkan hasil analisis data angket tingkat kecemasan terhadap ujian matematika pada Tabel 2, dapat dilihat bahwa persentase siswa yang tidak memiliki masalah kecemasan terhadap ujian matematika adalah 50\% atau sebanyak 4 siswa, siswa yang belum bisa dipastikan apakah terindikasi masalah kecemasan terhadap ujian matematika atau tidak adalah 37,5\% atau sebanyak 3 siswa, siswa yang terindikasi kecemasan terhadap ujian matematika dalam kategori rendah (masih kesulitan dengan matematika) adalah 12,5\% atau sebanyak 1 siswa, sedangkan siswa yang terindikasi kecemasan terhadap ujian matematika adalah 0 . Hal ini menunjukkan bahwa tingkat kecemasan siswa terhadap ujian matematika sangat rendah.

Kecemasan adalah suatu kondisi yang tidak menyenangkan meliputi rasa takut, rasa tegang, khawatir, bingung, tidak suka yang sifatnya subjektif dan timbul karena adanya perasaan tidak aman terhadap bahaya yang diduga akan terjadi. (Ramadan, 2019). Sementara kecemasan matematika adalah perasaan tertekan, kegelisahan bahkan ketakutan yang tercampur dengan kesalahan yang luar biasa pada angka dan memecahkan soal matematika. Sehingga dapat disimpulkan kecemasan adalah situasi yang dialami seseorang ( siswa) berupa perasaan tidak menyenangkan ketika menyelesaikan masalah matematika yang dapat mengganggu prestasi matematika seseorang (Sakarti, 2018). Kecemasan matematika dengan 
kemampuan matematis siswa memiliki hubungan yang negatif. Hal ini berarti bahwa jika siswa mengalami kecemasan matematika yang tinggi, maka kemampuan matematika siswa tersebut rendah. Tingkat kecemasan siswa sangat berpengaruh terhadap prestasi belajarnya. Apabila siswa mampu mengendalikan kecemasannya maka siswa tersebut akan mampu mengoptimalkan kemampuannya dalam belajar matematika (Ulya \& Rahayu, 2017).

Secara umum, pembelajaran matematika masih berorientasi pada guru. Pembelajaran ini berdampak pada rendahnya ketertarikan siswa dalam belajar matematika. Ketertarikan siswa terhadap matematika yang rendah berdampak pada tingginya kecemasan matematika siswa. Kecemasan matematika siswa yang tinggi akan berdampak pada rendahnya kemampuan literasi matematika siswa (Ulya \& Rahayu, 2017). Pada hasil analisis diperoleh bahwa 4 dari 8 siswa merasa tidak memiliki kecemasan terhadap ujian matematika. Mereka menunjukkan ketertarikan pada pelajaran matematika, tetapi mereka tetap mengganggap matematika merupakan pelajaran yang sulit dan merasa khawatir karena tidak tahu cara belajar dalam mempersiapkan ujian matematika. Pada dasarnya kecemasan dalam tingkat yang rendah dan sedang berpengaruh positif terhadap penampilan belajar siswa, salah satunya dapat meningkatkan motivasi belajar, sedangkan kecemasan siswa pada taraf yang tinggi dapat mengganggu dan memperburuk perilaku belajar siswa (Indiyani \& Listiara, 2006). Kecemasan yang dialami siswa dapat dijadikan stimulus yang berguna bagi siswa itu sendiri. Menanamkan rasa percaya diri kepada siswa bahwa mereka bisa memahami dan menyelesaikan persoalan matematika, serta menghilangkan prasangka negatif mengenai pelajaran matematika merupakan hal yang dapat dilakukan untuk meminimalkan kecemasan siswa pada pelajaran matematika (Wicaksono \& Saufi, 2013).

Sementara terdapat 3 siswa yang masih belum bisa memastikan apakah mereka merasakan kecemasan matematika atau tidak. Karena kebanyakan siswa yang merasa cemas dalam menghadapi ujian matematika, mereka tidak merasa bahwa itu merupakan perasaan yang dapat mengganggu kinerja mereka dalam menghadapi pelajaran matematika atau ujian matematika (Disai, Dariyo, \& Basaria, 2014). Berbeda dengan 1 siswa lainnya yang merasakan kecemasan dalam menghadapi matematika. Siswa yang merasakan kecemasan matematika tentu mengganggap matematika merupakan pelajaran yang sulit. Tingkat kepercayaan diri siswa yang kurang serta tidak adanya upaya untuk meminimalisir kecemasan 
tersebut mengakibatkan hasil ujian matematika siswa rendah. Hasil penelitian sebelumnya menemukan hal yang sama. Penelitian yang dilakukan Rosadah menemukan bahwa kecemasan dianggap sebagai salah satu faktor penghambat belajar yang mengganggu kinerja fungsi-fungsi kognitif, seperti mengalami kesulitan dalam menyelesaikan masalah matematika (Sakarti, 2018).

Kecemasan matematika cenderung terjadi pada seseorang dengan kemampuan matematika kurang. Artinya, individu dengan kecemasan matematika tinggi memiliki keterampilan atau latihan yang lebih sedikit dengan individu yang memiliki kecemasan matematika rendah. Individu dengan kecemasan matematika cenderung menjauhi kelas matematika dan belajar sedikit matematika dalam pelajaran yang mereka ambil. Pengaruh sosial dan kemampuan kognitif siswa cenderung menjadi sebab kecemasan matematika di sekolah. Pengaruh sosial siswa berasal dari guru yang cemas tentang kemampuan matematika dirinya sehingga memberi sikap negatif pada beberapa siswa mereka. Sedangkan pengaruh kemampuan kognitif disebabkan oleh keterampilan dasar yang lemah, misalnya lemah dalam menghitung atau memahami bangun ruang akan menyebabkan berkembangnya kecemasan matematika (Novikasari, 2016). Kecemasan yang terlalu berlebihan akan mempengaruhi kehidupan akademik siswa dan berakibat pada rendahnya motivasi siswa, strategi yang buruk dalam belajar, evaluasi diri yang negatif, kesulitan berkonsentrasi serta persepsi kesehatan yang buruk. Selain itu hasil penelitian membuktikan bahwa tingginya kecemasan siswa dalam menghadapi ujian berefek buruk terhadap cara belajar, kompetisi akademik, kepercayaan diri, penerimaan diri maupun konsep diri siswa (Nurlaila, 2011).

Siswa cenderung lebih cemas pada proses ujian dan seringkali ketakutan (kecemasan tes matematika), dan yang lain takut mengambil kelas matematika, hal ini dapat terjadi di sekolah dasar, sekolah menengah, sekolah tinggi atau tingkat kampus (kecemasan pelajaran matematika). Beberapa siswa kadang menyikapi ujian sebagai suatu permasalahan dalam hidupnya, baik karena nantinya ia akan malu karena tidak mendapat nilai yang bagus maupun karena merasa tidak percaya diri dengan persiapan yang dimilikinya. Perasaan takut atau tegang dalam menghadapi suatu persoalan tersebut disebut kecemasan (Ramadan, 2019). Oleh karena itu, kecemasan matematika dan hasil ujian matematika atau prestasi belajar matematika memiliki hubungan negatif, semakin tinggi prestasi belajar matematika maka semakin tinggi kecemasan matematika mahasiswa (Novikasari, 
2016). Karena hasil ujian matematika yang diperoleh menjadi tolak ukur untuk mengetahui ukuran seberapa jauh seorang siswa menguasai materi, sehingga siswa merasakan kecemasan tiap menghadapi ujian matematika (Disai, Dariyo, \& Basaria, 2014).

\section{Kesimpulan}

Berdasarkan hasil penelitian dan pembahasan dapat disimpulkan bahwa tingkat kecemasan siswa kelas XI SMA Negeri 23 Kabupaten Tangerang terhadap ujian matematika adalah sangat rendah. Kecemasan dalam tingkat yang rendah dan sedang berpengaruh positif terhadap penampilan belajar siswa, salah satunya dapat meningkatkan motivasi belajar, sedangkan kecemasan siswa pada taraf yang tinggi dapat mengganggu dan memperburuk perilaku belajar siswa. Kecemasan dengan tingkat rendah dan sedang yang dialami siswa dapat dijadikan stimulus yang berguna bagi siswa itu sendiri. Menanamkan rasa percaya diri kepada siswa bahwa mereka bisa memahami dan menyelesaikan persoalan matematika, serta menghilangkan prasangka negatif mengenai pelajaran matematika merupakan hal yang dapat dilakukan untuk meminimalkan kecemasan siswa pada pelajaran matematika.

\section{Ucapan Terimakasih}

Ucapan terimakasih ditujukan pada pihak-pihak yang telah mendukung keterlaksanaan penelitian ini.

\section{Daftar Pustaka}

Agustina, S., Santoso, E., Jatisunda, M. G., \& Majalengka, U. (2019). Terhadap Kemampuan Berpikir Kritis Melalui Model Auditory. Seminar Nasional Pendidikan, FKIP UNMA, 635-640.

Anfus, N. (2019). Perbandingan Kecemasan dan Hasil Belajar Matematika Antara Siswa SMP dan MTs. Pediamatika: Journal of Mathematical Science and Mathematics Education, 01(01), 77-90.

Handayani, S. D. (2016). Pengaruh Konsep Diri Dan Kecemasan Siswa. Jurnal Formatif, 6(1), 23-34.

Indiyani, N. E., \& Listiara, A. (2006). Efektivitas Metode Pembelajaran Gotong Royong (Cooperative Learning) Untuk Menurunkan Kecemasan Siswa Dalam 
Menghadapi Pelajaran Matematika (Suatu studi Eksperimental pada Siswa di SMP 26 Semarang). Jurnal Psikologi Universitas Diponegoro, 3(1), 10-28.

Nofrialdi, I. (2018). Tingkat Kecemasan Matematika Siswa SMA Negeri 2 Kerinci Kelas X MIA Sebelum Menghadapi Tes Matematika Berdasarkan Gender dan Hubungannya dengan Hasil Belajar. Edumatika Jurnal Riset Pendidikan Matematika, 1(November), 11-20.

Novferma, N. (2016). Analisis Kesulitan Dan Self-Efficacy Siswa SMP Dalam Pemecahan Masalah Matematika Berbentuk Soal Cerita. Jurnal Riset Pendidikan Matematika, 3(1), 76-87.

Novikasari, I. (2016). Hubungan Antara Prestasi Belajar Dan Tingkat Kecemasan Matematika Pada Mahasiswa Calon Guru SD/ MI. 5(2), 120-127.

Nurlaila, S. (2011). Pelatihan Efikasi Diri Untuk Menurunkan Kecemasan Pada Siswa-Siswi Yang Akan Menghadapi Ujian Akhir Nasional.Guidena: Jurnal Ilmu Pendidikan, Psikologi, Bimbingan Dan Konseling, 1(1), 1.

Ramadan, D. (2019). Kecemasan Siswa Dalam Belajar Matematika. (May). Retrieved from https:/ / www.researchgate.net/ publication/ 333076983

Sakarti, H. (2018). Hubungan kecemasan dan kemampuan siswa dalam menyelesaikan masalah matematika. Jurnal Pendidikan Informatika Dan Sains (JPIS) , 7(1), 28-41.

Siregar, N. R. (2017). Persepsi Siswa Pada Pelajaran Matematika: Studi Pendahuluan Pada Siswa yang Menyenangi Game. Prosiding Temu Ilmiah X Ikatan Psikologi Perkembangan Indonesia, 224-232.

Ulya, H., \& Rahayu, R. (2017). Pembelajaran Etnomatematika Untuk Menurunkan Kecemasan Matematika. Jurnal Mercumatika : Jurnal Penelitian Matematika Dan Pendidikan Matematika, 2(2), 16-23.

Wagetama. I, D., Dariyo, A., \& Basaria, D. (2014). Hubungan Antara Kecemasan Matematika Dan Self-Efficacy Dengan Hasil Belajar Matematika Siswa Sma X Kota Palangka Raya. 556-568.

Wicaksono, A. B., \& Saufi, M. (2013). Mengelola kecemasan siswa dalam pembelajaran matematika. Prosiding, 9(4), 90-94.

Zahro, Y. A., \& Purwaningsih, D. (2018). Pengaruh Kecemasan Matematika Siswa Terhadap Kemampuan Mengerjakan Soal Ujian Nasional.5(2), 169-186. 